\title{
'n Verkenning van postmodernisme en 'n ekskurs op Daniël 7-12
}

\author{
P M Venter \\ Departement Ou-Testamentiese Wetenskap (Afd A) \\ Universiteit van Pretoria
}

\begin{abstract}
A reconnaissance into post-modernism and an excurs on Daniel 7-12

This orientation to the contents and meaning of postmodernism, investigating its relation to poststructuralism and its literary implications for exegesis, proposes that Daniel 7-12 can be read as sub-or minor narratives.
\end{abstract}

\section{VRAAGSTELLING}

Uit 'n vorige ondersoek (Venter [1997b]) na die moontlikheid om Daniël 9 uit die hoek van intertekstualiteit en montage te lees, het dit duidelik geword dat hierdie begrippe nie sonder hulle poststrukturalistiese belading gebruik kan word nie. Hulle dui op die daarstelling van 'n metafoor waarin daar op 'n holistiese wyse inklusief en allesomvattend na die werklikheid gekyk word. Die eksistensiële situasie van die mens in die wêreld word gesien as die van ' $n$ wese wat binne relasies staan met alles en almal wat hom/haar omring . Alles en almal is voortdurend in 'n netwerk verweef en interaktief op mekaar ingestel. Alle taaluiting sit vasgevang binne die dialektiek van bestaan en in die polifonie van dialektiese uitsprake. Taal, kuns, literatuur en teologiese tekste is die resultaat van 'n wisselwerking tussen verskillende vlakke van betekenis, tussen teenstrydighede. Dit is die interaksie tussen eie ervaring en ander interpretasies, hetsy van ouer tekste, hetsy van eietydse uitsprake. Dit is 'n kreatiewe poging om die konflikterende wêreld te orden en te interpreteer. Dit is metaforiseer en hermetaforiseer om sin van die werklikheid te probeer maak.

Wanneer postmoderne literatuur en literatuur óór die postmodernisme gelees word, val die raaklyne met hierdie sienswyse in die poststrukturalisme dadelik op. Dit bring vrae na vore oor die ooreenkomste en verskille tussen hierdie twee sienswyses, na die literêre implikasie daarvan vir die eksegese en die resultate wat 'n postmoderne lees van die Daniëlapokalips (Daniël 7-12), kan oplewer. Wat volg, is enkele perspektiewe wat uit die worsteling met hierdie hierdie vrae ontwikkel het. 


\section{DIE DANIËLAPOKALIPS EN GRENSLITERATUUR IN AFRIKAANS}

Daar is 'n opvallende ooreenkoms tussen die Daniëlapokalips en die vrae wat in die jare tagtig in die Afrikaanse literatuur oor die Suid-Afrikaanse grensoorlog gevra is. In die Afrikaanse literatuur is gepoog om '... ágter die haplografie van amptelike weergawes ... in te beweeg en die individu se ervaring van 'n geweldsamelewing te probeer dokumenteer' (Van Heerden 1997:76) en literatuur te skep '... waar die verskrikking van geweld en die effek daarvan op mense beskryf word' (Van Heerden 1997:77). Skrywers het '... die onvermoë van taal om die werklikheid ... die ontsetting van krygsuitputting ... uit te beeld' (Van Heerden 1997:77) ervaar. Dit stem ooreen met die ervaring in die Daniëlapokalips van ' $n$ vors wat 'die heiliges van die Allerhoogste vervolg' (Dan 7:25); wat 'ongelooflike verwoesting aanrig ... magtiges vernietig, ook die heilige volk' (Dan 8:25); van 'hierdie groot onheil oor ons ... nog nooit op die aarde so iets gebeur soos in Jerusalem nie' (Dan 9:13); van 'die stad en die heiligdom sal verwoes word' (Dan 9:26); van 'einde ... soos 'n oorstroming ... oorlog ... tot die einde toe, rampe ... (Dan 9:26); van die leiers van die volk word doodgemaak, verbrand, gevange geneem en geplunder (Dan 11:33); van 'n tyd wat kom 'so swaar soos dit nog nooit was vandat daar nasies is nie' (Dan 12:1).

Die ooreenkoms geld nie soseer die universele ervaring van die trauma van oorlog nie, maar gaan meer oor die verwoording van die ervaring en die funksie van taal om dit te doen.

Die verwoording van die Daniëlapokalips is afkomstig van 'n Trägerkreise wat 'n gevoel van veronregting of ontneming ervaar het en vanuit 'n millenniaristiese perspektief die gebeure in Jerusalem gedurende die tweede dekade voor Christus as 'n grenslose krisis beleef het ( $\mathrm{vgl}$ Venter 1996:619-630). Hulle '... skans hulle af teen die drastiese hervormings van Antiogus en die teologies-modernistiese maatreël van sy handlanger Menelaos, sowel as teen die elite groepe wat die kultus wil beheer. Hulle grens hulleself eweneens ook af teen die ander versetgroepe: teen diegene wat hulle tot gewapende verset wend, maar ook die wat 'n onrealistiese Naherwartung koester' (Venter 1996:631).

Soos in die Afrikaanse grenstekste is die Daniëlapokalips '... 'n inskryf van die persoonlike kleingeskiedenisse téén die groot metanarratiewe van die tyd ...' (Van Heerden 1997:78). Gedurende hierdie tyd het daar 'n versteuring in die sosiale orde in Jerusalem na vore gekom. Sommige van die ondersteuningsgroep ('retainer class') wat in diens van die regerende groepe was en verantwoordelik was vir die uitvoering van hulle beleid, het in konflik met hulle beland. Hulle was verantwoordelik vir die handhawing van wat Redfield die 'great tradition' noem (vgl Redfield 1956:70-72). Dit was die amptelike godsdienstradisie soos dit deur die elite gesanksioneer en deur die priesters en godsdienslui gekultiveer en gesaghebbend oorgedra is. Met die vervolging deur Antiogus IV Epifanes word die tempel ontwy en die tempelpersoneel verplig om deel te neem aan 'n sinkretistiese kultus waarin offers aan Zeus Olimpos gebring moes word. 
Dit het teologiese veranderings meegebring wat as ' $n$ afwyking van die groot tradisie ervaar is. Daar moes gevolglik teruggeval word op wat Redfield die 'little tradition' noem. Dit was die onamptelike tradisie wat onder die gewone volk geleef het. Volgens Horsley \& Hanson (1985:3) was daar by die gewone lui '... ideals of what life should be like, and a memory which informed and. buttressed those ideals'. Tempelpersoneel wat teen die optrede van Antiogus in verset kom, neem dan hierdie kleintradisie van die gewone volk op. Hulle maak daarvan die tradisie wat hulle voorstaan en propageer téén die 'verworde' tradisie wat deur die leiersgroepe en hulle meelopers in uitvoering van Antiogus se gesag gehandhaaf word (vgl Venter 1997:73-74). Téén die groot metanarratief van die tyd van Hellenisering en sinkretisme skryf hulle die kleingeskiedenis in van hulle hermetaforisering van die tradisionele metafoor van vertroue dat God in volkome beheer is van tyd en ruimte.

Hierdie inskryf by die Daniëlapokalips van petite histoires vanuit 'n posisie van onmag om uiting te gee aan 'n gruwelsituasie wat bo die eie mag uitgaan, stem baie ooreen met wat in postmoderne grensliterauur voorkom en wat Lyotard 'countermemory' noem. Meesternarratiewe word gewoonlik ontwerp en met behulp van die infrastruktuur van sosiale mag die wêreld ingestuur om die saak/illusie van 'n universele menslike storie te onderbou en te legitimeer. Uit die memory van die gewone lui (vgl Horsley \& Hanson hierbo) word die teenverhale of 'kleingeskiedenisse' (Van Heerden 1997:44) gebore wat op die meesternarratiewe ingryp en hulle totalitarisme ondermyn. Dit is die eienskap van postmoderne tekste dat dit op hierdie kleingeskiedenisse fokus en hulle sentraliseer. 'Die postmodernistiese teks wil dus inskryf téén die wyse waarop politici of kultuurleiers meesterverhale aan die gewone mens wil opdwing ten einde politieke of kulturele opposisie uit te wis' (Van Heerden 1997:44-5).

\section{POSTMODERNE LITERATUUR OF POSTMODERNE LEES?}

Die raaklyne tussen die Daniëlapokalips en postmoderne grensliteratuur bring die vraag na vore of hierdie apokalips dan as postmoderne literatuur beskou moet word. Dit vereis ' $n$ nader omskrywing van wat postmoderne literatuur is. Dit lei op sy beurt na besinning oor die begrip 'postmodern/isme'.

'n Postmoderne teks tematiseer eksplisiet die standpunte wat in die verskillende weergawes van postmodernisme gehuldig word. Dit wend 'n doelbewuste poging aan om teen die 'moderne' en teen die gevestigde in te gaan. Dit is tekste waarin gestreef word 'to defamilirize the representation of reality, thereby perhaps forcing the reader to rethink his notion of "the world ouside"...(Gräbe 1988:369). Dit is '...tekste wat nabootsing/opsturing is van ander tekste en/of los/alogies gestruktureer is...' (Hambidge 1995:77). 
Daarteenoor is die teks nie per se postmodernisties nie, maar is die leser so beïnvloed deur die kodes van postmodernisme dat alle tekste vir hom/haar elemente hiervan vertoon. Ouer werke word dan vanuit 'n poststrukturalistiese raamwerk gelees. Postmodernisme word by die leser '... 'n diskursiewe ruimte, 'n klimaat waaruit 'n lesing van 'n teks onderneem kan word' (Van Heerden 1997:17). Dit word 'n manier van kyk, 'n heuristiese instrument, 'n strategiese ondersoekapparaat, 'n leesstrategie waarmee vanuit 'n postmodernistiese invalshoek na 'n saak gekyk kan word (vgl Van Heerden 1997:17)

Die Daniëlapokalips is nie per se postmoderne literatuur nie. Dit vertoon egter'n postmoderne klimaat wat geskik is vir 'n postmoderne leesstrategie. As versameling van kleingeskiedenisse wat teen die meesternarratief van sy tyd inskryf, adem dit die lug van 'n diskoers wat die absoluutheid van elke diskoers ondermyn en aandring op die marginalisering van elke diskoers.

\section{WAT HOU DIE BEGRIP POSTMODERNISME IN?}

Die neiging van postmodernisme om teen die grein in te gaan en vir die marginale te kies, reflekteer die wesenlike geaardheid van postmodernisme. Dit is '....a movement of resistance' (Adam 1995:1). Dit bied in die eerste plek weerstand teen die denke van die 'moderne'. Dit is hiperkritiek, '...kritiek tot by die tweede en derde mag' (Louw 1995:11), op al die kritiese beginsels en teorieë wat die menslike rede ontwerp het. Dit is ' $n$ epistemiese beweging weg van die groot metanarratief wat sedert die Renaissance die moderne ervaring gereguleer het. Die metanarratief van die modernisme met sy rasionaliteit, objektiviteit, samehang (coherence) en universaliteit, reflekteer nie meer genoegsaam al die ervarings van die wêreld vandag nie. Die verabsolutering van die rasionele in die modernisme lok weerstand uit. Daar word afskeid geneem van absolutisme, universalisme, eenheid, intellektualiteit en totalitariteit. Die postmoderne denke is 'n agterdogtige kulturele respons op die metanarratief van die moderne wat nie sy vanselfsprekendhede deel nie en nie saamgaan met die twee moderne mites van die bevryding van die mensheid en die spekulatiewe eenheid van alle kennis nie. Daar is '... no longer any interest in unity ...' (De Villiers 1991:147). Postmoderne denke is '... antifoundational, antitotalizing, and demystifying' (Adam 1995:22).

In postmodernisme is daar ' $n$ veranderde diskursiewe diskoers. Teenoor die moderne diskoers sien die postmoderne diskoers die mens nie meer as die middelpunt van taal, wêreld en betekenis nie, benader hy nie meer alles net rasioneel nie, gaan dit nie om die eksploitasie van alles wat geken kan word nie en gaan dit nie meer om 'n metanarratief wat slegs sekere vorms van kennis en sosiale instellings begunstig nie. Die moderne word eerder gedestabiliseer en die magte daaragter uitgedaag. In plaas 
van 'n sentrum is daar eerder 'n pastiche, 'n kulturele hersamestelling. Enigiets word met enigiets gejukstaponeer. Die klem val op die ongedagte, die vergete. Die kritiese self as die houer van kennis word bevraagteken en vervang met 'n ander gedagte. 'Rather, the self of the postmodern epoch is to be seen as emerging as a product of its local material, historical conditions' (Phillips 1990:23). Die self word verplaas '...to the margins, by insisting upon the dispersion and multiplication of voices, technologies, methods and frameworks for knowing' (Phillips 1990:23). Absolute sekerhede maak hier plek vir beperkte sekerhede, wat ingebed is '.. binne 'n netwerk van relasies en spesifieke kontekste' (Louw 1995:11). Daar word aangesluit by Marx se situering van die mens binne die verhouding tot die strukture van sosiale produksie van waardes en by Freud se analise van betekenis as ' $n$ bewustelike/onbewustelike konflikterende proses: 'man/woman is in a very important way a function of his/her social, psychological, political and economic circumstances' (Phillips 1990:23).

Hoewel postmodernisme oënskynlik chronologies op modernisme volg, moet dit nie met periodisering of historisiteit verbind word nie (vgl Brink 1988:392). Dit is eerder ' $n$ reaktiewe tendens wat in die laat twintigste eeu opvallend dominant is, maar deur die loop van die geskiedenis steeds aanwesig was. Louw (1995:11) sien dit as 'n '... kulturele tendens in ons samelewing ....' Dit is '... 'n bepaalde ethos, 'n manier van dink en doen ...' (Louw 1995:11), 'n bepaalde geestesklimaat. Dit is 'n fenomeen met geen eenduidigheid nie, maar ' $n$ swewende beweging wat in baie gestaltes manifesteer. Van Heerden (1997:14) noem dit 'n 'nomadiese diskoers'. Vir Phillips is die begrip '.. not reducible to a concept, method or practice specific to a discipline, field of knowledge or school of thought but characterizes a transformative discourse - an attitude as much as an age - that cuts across late twentieth century disciplinary and cultural practices' (Phillips 1990:20; my beklemtoning).

Die herskepping (of hermetaforisering, soos hierbo aangedui) van die postmoderne diskoers, bestaan enersyds in die '... pulverisering van definisies en kategorisering ...' (Brink 1988:381). Anderyds lui dit 'n 'radikaal nuwe poëtika' (Van Heerden 1997:15) in. Dit werk met 'n pluriformiteit van verskynsels soos verskeidenheid en fragmentasie, ontginning van die boek as artefak, anti-elitisme en anti-autoritarianisme, wegbeweeg van die mitiese na die eksistensiële, opstand teen alle tradisionele Westerse waardes, oopheid in alle rigtings, 'n bewustheid van tydelikheid (vgl Brink 1988:3812). Veral die vrae oor betekenisproduksie kom na vore. Die gemene deler in al hierdie onderskeie manifestasies van postmodernisme is egter vir Van Heerden '... 'n besinning oor die krisis van representasie en 'n problematisering van die verhouding tussen woord en wêreld ...' (Van Heerden 1997:249; my beklemtoning). 


\section{DIE KRISIS VAN REPRESENTASIE}

Die 'post'-attribuut van postmodernisme plaas dit van meet af aan in 'n tweede linie van presentasie. Die 're-' van sy representasie stel dit in verhouding met wat present (teenwoordig) is, maar ook met wat reeds gepresenteer (aangebied) is in bestaande literatuur. Dit werk met 'n metanarratief wat in konkurrensie met 'n bestaande modernistiese meesterverhaal staan, maar wat in sy verwoording van die werklikheid voor die dilemma staan dat dit alleen iets nuuts kan sê deur dit wat reeds gesê is van voor af oor te sê. Die krisis van die postmodernisme lê daarin dat dit altyd van daardie verwoording van die werklikheid gebruik moet maak waarvan dit juis wil wegkom. Dit kan nooit iets sê sonder om dit in terme van dit wat reeds gesê is, te formuleer nie.

Dit word duidelik in Hambidge (1992a:62) se definisie van postmodernisme as '... 'n kunsbeweging wat die grense van die kunsmedium ondersoek, (her)definieer en verironiseer'. Die grense word getoets deur bestaande werke te gebruik om die nuwe teks daar te stel. So word daar 'n parallele teks geskep wat die oorspronklike boodskap teenoor 'n postmoderne interpretasie stel. Die postmoderne teks verkry so 'n 'spanning van opposisies' (Hambidge 1992b:49). In die intertekstuele teenoormekaar stel van die oorspronklike en die nuwe teks vind 'n parodisering plaas. Die kontrasstelling lig die 'banale' (Hambidge 1992b:49) uit, dit '... banaliseer die oorspronklike kunswerk' (Hambidge 1992a:62).

Hierdie parodisering is vir Hambidge (1992b:48) '... sekerlik die belangrikste uitvloeisel van die post-modernisme en terselfdertyd die ingewikkeldste modus van hierdie beweging'. Dit is '... die mees sentrale voertuig van die post-modernisme. 'n Mens sou kon aanvoer dat die parodie as 't ware ál die beginsels en kenmerke van die post-modernisme beklemtoon, juis omdat dit die Romantiese estetika van "oorspronklikheid", "individualiteit", en so meer dekonstrueer' (Hambidge 1992b:56).

Die parodie is afhanklik van die bestaande werk en veronderstel kennis daarvan en teer daarop. Dit gaan '... om die "already-said", die reeds-gesêde wat nuut/anders voorgestel word' (Hambidge 1992a:62). Dit '... word nie verniet 'n estetiese kannibalisme genoem nie' (Hambidge 1992b:48). Dit sou gewoon nabootsing of pastiche van die oorspronklike teks wees as daar nie parodisering van die oerteks plaasvind nie. Deur parodisering word ' $n$ ironiese en grappige blik op sake gewerp en 'n nuwe toevoeging gemaak (vgl Hambidge 1992b:49). Tegelyk word die bestaande teks daardeur bevraagteken en bekende kategorieë deurbreek. So is parodie altyd 'n erkenning én 'n dekonstruksie van die oorspronklike.

\section{POSTMODERNISME EN POSTSTRUKTURALISME}

Die postmoderne kannibalisering en parodisering van bestaande tekste bring noodwendig die vraag na vore na die verhouding tussen postmodernisme aan die een kant en 
intertekstualiteit/dekonstruksie/postrukturalisme aan die ander kant. Postmodernisme maak van die woordeskat van poststrukturalisme en die dekonstruksie se "begrippeapparatuur' (Hambidge 1992a:63) gebruik. Hoewel die twee begrippe nie volledig oorvleuel nie (vgl'Brink 1988:380) en ook nie dieselfde uitgangspunte deel nie (vgl Van Heerden 1997:27), is daar 'n onvermydelike interafhanklikheid van poststrukturalisme en postmodernisme. Postmodernisme kan '... nié sonder dekonstruksie funksioneer nie ...' (Hambidge 1995:75). Die twee konsepte is voortdurend op mekaar aangewese. Die afhanklikheid is egter groter aan die kant van die postmodernisme. Volgens Van Heerden (1997:27) domineer die poststrukturalistiese diskoers, veral vanuit Derrida se dekonstruksie, die postmodernistiese debat. Vir Brink en Rabinovitz is 'n poststrukturele raamwerk essensieel vir die verstaan van die postmodernisme met sy '... typically disruptive features by which literary texts seemingly attempt to undermine reader expectation or to question critical observation regarding both the nature of language and the notion of representation in literature' (Gräbe 1988:362).

Die twee sluit bymekaar aan omdat bekende hiërargieë bevraagteken word en klem gelê word op difference en pluraliteit. In intertekstualiteit is die fenomeen teks herdefinieeer en word dit gesien as deel van 'n netwerk van verwysings na ander tekste; die teks word binne 'n proses van betekenisproduksie gesien; en die rol van die leser word sterk beklemtoon (vgl Vorster 1989). Die nosie van die palimpses soos dit deur Fokkema hanteer is, onderstreep Kristeva se opvatting van intertekstualiteit, wat klem lê op die onontkombare verhouding van elke teks tot ander tekste en by implikasie die aktiewe rol wat die leser speel om betekenis aan die teks te heg binne hierdie netwerk van tekste.

Die teks binne ' $n$ netwerk van tekste verkry eers betekenis deur die aktiewe rol van die leser omdat ' $n$ teks in intertekstualiteit meer is as net 'n verbale uiting. Onder 'teks' word verstaan '... a set or complex of signs, which is to be interpreted against the background of other signs or sets/complexes of signs' (Voelz 1989:28). Die reseptor is egter ook 'n teks wat ter sprake kom. Wanneer die leser lees, tree sy/haar eie verwyingsraamwerk óók as betekenisgewer op: ' $\ldots$ he also reads simultaneously his own life-experience as sign and relates it and its potential meaning to the signs and to the meanings of those signs on the various levels which comprise a text, to make sense of his own life-experience as sign, i.e., to apply the text to himself' (Voelz 1989:33). In die leser-georiënteerde benaderings word van die leser se teks na die geleesde teks beweeg. 'Indeed, it is this sort of intertextuality, proceeding from the life-experience text of the interpreter to the text in question, which has taken on such overarching importance in the so-called 'post-modern' approach to literary texts' (Voelz 1989:33). 
Dekonstruktiewe denke doen in aansluiting hierby weg met die veronderstelling dat woorde na dinge verwys. Dit is 'aanpaksels' (Hambidge 1992a:64) wat nie langer opgaan nie. Iets bestaan nooit op sy eie nie. Daar is ook geen noodwendige samehang tussen betekenaar en betekende nie. Dekonstruksie bestry hierdie logosentrisme en ontken die dominansie van die woord as die enigste betekenisdraer. Iets bestaan telkens in terme van iets anders, in binêre spanning daarmee. Op grond van die onderskeid met iets anders (difference) vind dit sy bestaan. Dit vind sy identiteit alleen in terme van iets anders, van 'n leser en 'n situasie. Binne hierdie netwerk vind daar danksy die - aktualiseringspotensialiteit van taal 'n hipokodifikasie (Umberto Eco) plaas. 'n Teks word geskep wat in referensiebetrekking staan, nie net tot die aktuele wêreld van die leser nie, maar ook tot literêre referensie wêrelde. Meer nog, 'n teks word in die netwerk geskep wat in referensie met die werklikheid staan. Vir dekonstruksie is hierdie werklikheid allermins eenvoudig. Die werklikheid is '... immers ook 'n Teks: gebroke, óndeurdringbaar, onbegrypbaar, onaf' (Hambidge 1992a:64). En dit is juis hierdie ingewikkeldheid wat die postmodernisme reflekteer.

Postmodernisme floreer dus op die bepaalde siening van intertekstualiteit en dekonstruksie oor die aard en funksie van 'n teks. Dit neem die saak een tree verder en problematiseer dit tot by die punt van die absurde, soos dit duidelik sal word uit wat volg.

\section{DIE VERHOUDING TUSSEN WOORD EN WERELD}

Die parodisering van tekste, waarna hierbo verwys is, werk op twee vlakke gelyk. Dit het altyd 'n intertekstuele verbintenis met die teks wat geparodiseer word, maar dit parodiseer tegelyk die werklikheid. Dit is tegelyk ook 'n vorm van sosiale kommentaar. 'Nie alleen word die gemeenskap of die sosiale orde gekritiseer nie; ook literatuur word in hierdie tekste gedekonstrueer' (Hambidge 1992b:51). Die wêreld van die teks, maar ook tegelyk die reële wêreld kom onder die loep.

'n Bestekopname word van die kunswerk se tekstuele status gemaak. Die skrywer is '.. besig om ons attent te maak dat kuns representasie is en telkens heenwys na ander bestaande tekste. Dit is ook 'n manier waarop 'n skrywer 'n bestekopname maak en as 't ware tot terme kom met die intimiderende tradisie waarbinne geskryf word' (Hambidge 1992b:53). Hoewel hierdie soort teks die kreatiewe verheerlik, bly dit bewus van die '... onsekerheid van representasie ...' (Hambidge 1992b:50). Parodiserend en speels word tegelyk bytende kritiek op die werklikheid gelewer. Postmodernistiese tekste is '... voortdurend besig om die grense tussen fiksie en werklikheid te ondersoek én verskuif' (Hambidge 1992b:51). Dit '... defamiliariseer al die bekende konvensies deurdat die outoriteit van die skrywer ondermyn word, die "finale 
einde" uitbly en 'n definitiewe interpretasie ónseker is' (Hambidge 1992b:50). Die grense van die literatuur word dus voortdurend verskuif en die verteller tree in hierdie sogenaamde 'surfiction' (Hambidge 1992b:51) as ' $n$ interpreteerder op in die teks. Die postmoderne teks is ' $n$ metafiksionele teks waarin oor die eie prosesse van teksproduksie nagedink word, en daardeur ook implisiet kommentaar op die werklikheid gelewer word. Dit gaan oor die vraag van die verwoordbaarheid van die werklikheid, die verhouding tussen taal en werklikheid, die spanning tussen woord en wêreld. As representasie van die werklikheid kan van literatuur verwag word dat dit meer sal wees as net 'n blote lewensgetroue weergawe of weerspieëling. 'Die literatuur lê iets bloot van die sin, die tipiese, selfs nog sterker: iets van die "waarheid" van die lewe' (Viljoen 1988: 422).

Die outeur word in postmoderne materiaal 'n gereedskapstuk vir die ontdekking en eksploitering van bestaan (ontologie). Die skrywer verskyn by tye self op die toneel om juis aanduiding te gee van die worsteling tussen outeurswerklikheid en tekswerklikheid. In postmodernisme word hierdie saak bykans oormatig geproblematiseer. Daar is 'n skerp bewustheid van die onmag van taal om 'n brug te slaan. Meer nog, geen ernstige leser van hierdie literatuur kan dit bekostig '.. to ignore the manner in which self-reflexive commentary on the artifice of writing seems to dictate an awareness of the artificiality of reality' (Gräbe 1988:377). Die postmoderne outeurs bevind hulle '.. in die paradoksale posisie dat hulle, ondanks taaltwyfel, hulle gedrewe voel om nogtans voort te gaan met die vertel van verhale' (Van Heerden 1997:78). Op soek na betekenisgewing en ten spyte van sy bewustheid van taal se onvermoëns word die mens skynbaar voortgedryf om ironies '... met juis taal ' $n$ bres na die werklikheid te probeer slaan' (Van Heerden 1997:57).

Dit gaan ook nie om klaar gevormde waarhede of uitgespelde reëls van die werklikheid nie, maar om die inspanning om die onuitsêbare te hanteer, ' $\ldots$ to invent allusions to the conceivable which cannot be presented (Lyotard 1984:81). Dit is 'n 'analities-referensiële diskoers' (Hambidge 1992a:62) waarin die outeur nie die houer van die waarheid is nie. Daar is 'n kritiese bewustheid van taal as sinkgat, as afwesigheid sonder patroon, as verraad teen elke poging tot singewing, van die breuk tussen werklikheid en woord (vgl Van Heerden 1997:246). Daar is ook 'n bepaalde weerstand teen en vervreemding van die geykte representasiepatrone en dominante representasieraamwerk van die moderne Weste. Dit bring 'n konflik mee deurdat 'n postmoderne voorstelling soms afgemaak word as 'n skim en selfs 'n vervalsing van die oorspronklike. Postmodernisme word uit moderne hoek getipeer met begrippe soos onbepaaldheid, fragmentering, narsissisme (of selfverlies), performatief, karnavaliserend, onvoorstelbaar, kosmologies, immanent. Die kritiek op postmodernisme is dat dit selfreferensieel 
is, homself bekommentarieer, narsissisties in 'n volslae solipsisime is, 'n kamer van spieëls. Volgens Viljoen word hierdie kritiek verskerp deurdat postmoderne werke doelbewus hulle gemaaktheid, hulle representasie-wees onderstreep (vgl Viljoen 1988: 421).

Die bewustheid van die onvermoë om die werklikheid in taal vas te vang, om taal en werklikheid bymekaar uit te bring, kom in die postmoderne werk in verskillende vorms tot uitdrukking. Verskillende tegnieke word gebruik om die leser te verwar, '... om eindigheid in kompleksiteit te verander' (Hambidge 1995:36). Gräbe (1988:371) sien dit by die tekste wat sy gelees het '... in the imaginative, phantasmagorical and fantastic portrayal of mimetic and marvelous worlds ...' Viljoen (1988:421) sien dit in die outeurs se pogings om hulle '... eie kosmologieë op te bou en so die mag van voorstelling te bewys'. Tegnieke vir verwarring word gebruik, soos metalepsis, oëverblindery deur trompe l'oeil, opsetlike verandering van een vlak van vertelling na 'n ander (vgl Hambidge 1995:36).

Die problematiese van representasie in postmodernisme word dikwels met metafore, soos die van die spieël, die 'labarint' en 'reis', uitgedruk. Vir die gebruik van die metafoor van die spieël en die labarint is die werk van Umberto Eco Il Nome della Rosa 'n baie goeie voorbeeld, veral die episode gedurende die nag van die tweede dag waarin William en Adson in die biblioteeklabarint van die klooster ronddwaal en in een van die vertrekke op 'n spieël afkom wat jou beeld vergroot en verdraai soos wat 'n mens vorentoe en agtertoe beweeg (vgl Eco 1984:181). 'n Labarinteffek word in die postmodernistiese teks verkry deur die gebruik van mise-en-abîme (vgl Hambidge 1995:36). Die metafoor van die labarint het met die dekonstruksie dat die letterkunde 'n wêreld in woorde is, te doen. Die teks is 'n verteenwoordigende uitbeelding van die werklikheid wat teenstrydig is, die eenvoudige wat gelaai is met intertekstualiteit, die gebrek aan eenheid in die werklikheid.

In Miscall (1992:103) se samevatting van sy ondersoek na die boek Jesaja kom iets na vore van die postmoderne gedagtes: '... like a journey through the Labyrinth, the tracing doesn't lead to a center or to a definite entrance or exit; rather, it constructs a Labyrinth which also serves as an image for the reading of Isaiah'.

In haar ondersoek van die verhaal van Ester, werk Bal met die rol van woorde, as magbeoefenaars, as dit wat iets doen. Dit gaan volgens haar in Ester om refleksie oor die beheersing van die werklikheid deur middel van taal en daarom 'n selfrefleksie oor die spieëling van die werklikheid in die labarint van die ontoereikendheid van die taaluiting. Sy noem Ester '... a self-reflexive text .... it reflects on the uncertain status of writing and the ways it produces reality ... a case of postmodernism avant la lettre' (Bal 1992:81). Die aantreklikheid van so 'n teks van selfreflekie lê nie in die deursig- 
tigheid daarvan nie, maar juis in die dubbelsinnigheid (ambiguity) daarvan, want dit '.. opens up the space for a view of representation unbound by the kind of psychological realism inherited from nineteenth-century western fiction' (Bal 1992:81; bedoelende modernisme). Self-reflekterende kuns hou die waarnemer gevange omdat dit ' $n$ relevante perspektief bied waaruit ons ' $n$ konsep kan kompliseer en historiseer. Selfrefleksie as 'n manier van lees binne 'n lees-georiënteerde teorie van teks sluit komplisering in wat in sy eenvoudigste vorm weergegee kan word deur die vraag: wie se, of watter self, word hier gereflekteer? 'The identity between the work and its subject - between work as labor and work as product - is not unified; it is fragmented by the intrusion of the reader whose position is inherently paradoxical: is $\mathrm{s} / \mathrm{he}$ part of the self being reflected or reflected on?' (Bal 1992:81-2).

Hierdie laaste opmerking bring on by die vraag na die rol van die leser in 'n postmoderne leesstrategie. Gaan dit by postmoderne lees oor die onverwoordbaarheid van die werklikheid uberhaupt, of ook selfreflekterend oor die leser se eie labarint van onvermoë?

\section{DIE LESER}

Poststrukturalisme verbind die leser aan betekenisgewing deur sake soos intertekstualiteit en dekonstruksie. Postmodernisme voer hierdie integrering van die leser nog een stap verder. Dit stem saam met die poststrukturalisme dat betekenis geen absoluutheid is wat agter, voor, of in die teks gevind kan word nie. Dit is iets wat in terme van binêre spanning en van verskil gevind moet word. 'Meaning is what we make of texts, not an ingredient in the text' (Adam 1995:33). Dit is egter veral die konteks van taaluiting (wat verskeie betekenismoontlikhede bied), die situasie waarin die betekenisgewing plaasvind, die ideologiese raamwerk, die sosiale konteks, wat hier voorop gestel word.

In die postmodernisme word die teks gesitueer eerstens binne die betekenisgewende gebeure en tweedens binne die historiese, sosiale en kulturele moment van produksie en resepsie. Die vraag word gevra: wie is aan die woord, uit watter posisie van mag, met watter bedoeling en met watter uitdaging aan die leser? Daar is altyd die bewustheid dat die skrywer wanneer hy/sy oor sy/haar eie tyd en die verlede praat, dit gekontekstualiseer doen. Wanneer hy dokumente uit die verlede gebruik is selfs dit ook gekontekstualiseer. Dit is nie meer moontlik om geskiedenis as blote mimetiese weergawe van die gebeure te sien nie. Daar word in hierdie opsig van 'historiografiese metafiksie' (Van Heerden 1997:73) gepraat. Feit en fiksie word etimologies aan mekaar vasgeskarnier tot 'n verskynsel wat die Amerikaners 'faction' noem en party op Afrikaans 'faksie' (vgl Van Heerden 1997:73). 
By aanbieding van historiese gebeure word telkens die vraag gevra na die magstrukture agter die subjek. Daar word gevra waar die meesternarratief vandaan kom. Ook die vraag word gevra na die perifere karakters, met hulle 'kleingeskiedenisse' (Van Heerden 1997:76), waarna reeds hierbo verwys is. 'n Worstelende dialoog met teks en historiese konteks word vereis waarin die historikus pynlik bewus is van sy eie kulturele en ideologies konteks waarin hy beweeg. Dit is wat Phillips op voetspoor van LaCapra noem '...a contestory dialogic practice that forces open the meaning of self and context to include, along with authorial intention, textual corpus, literary genre, biography, economic infrastucture, and modes of production' (kyk Phillips 1990:26). Die uitgangspunte van die vertelling en die struktuur daarvan, sowel as die ideologiese karakter daarvan word in radikale reflekterende terme omskryf.

Die teks kan egter nie as afgehandelde, geslote entiteit binne die betekenisgewende gebeure van produksie en resepsie gelees word nie. Daar is geen gestolde absoluutheid in die teks nie. Die teks is 'n multidimensionele ruimte wat met die interaksie van tekste, lesers en situasie werk. Daar is sprake van '... a shifting network of signs, texts and aporias of meaning that draws attention to the interaction of reader/subject and text in fundamentally social, material and discursive terms' (Phillips 1990:11; my beklemtoning).

Dit is 'n proses wat die outeur totaal op die agtergrond laat verdwyn. Die postmodernisme 'demistifiseer' (kyk Hambidge 1992a:65) die verhouding tussen die skrywer-produseerder en die leser-ontvanger. Die outoriteit van die outeur word in die postmoderne teks bevraagteken. Dit is vir Barthes die leser wat die aktiveerder van die kontekstuele netwerk is waarbinne die teks begryp moet word. Die outeur is nie meer die enigste of finale plek van betekenis nie. Dit word ' $n$ aangeleentheid van enunsiasie, 'n diskursiewe situasie. Die teks transendeer die outeur en noop die leser om aan die betekenisgewende gebeure deel te neem. Daar is ' $n$ 'postmodernist demand that the reader be co-producer of the text ...' (Gräbe 1988:370). 'n Uitnodiging word aan die leser gerig om teenwoordig te wees by die skryfhandeling. 'Die leser word medeskrywer, moet aktief as historiograaf meewerk, en kan geen passiewe verbruiker wees nie. Die verhaal word voor sy oë, en mét sy oë, geskryf ' (Van Heerden 1997:86). Die leser word as voyeur betrek. Sy/haar eie kleingeskiedenis word in die verhaal gesentraliseer. Die leser en sy/haar konteks word integrale deel van die betekenisgewende gebeure.

Deur metafiksionele strategieë soos die dood van die outeur, uitwissing deur die instrument van die palimpses en die fusie van feit en fiksie, spieël die teks nie net sy eie prosesse van produksie nie, maar ook die van die interteks. Dit dui 'n proses van produksie aan en dwing die leser op tipiese postmoderne wyse om na analogie daarvan 
self die teks se konstruksie te voltooi. Dit word onder andere reggekry deur episodes uit kontemporêre geskiedenis in die fiksie in te vleg '... which require the reader to erase the boundaries between story and history, in so doing, to place him- or herself in a relation of reader to both, thereby forcibly impressing on him/her that the political text is subject to a process of intertextual repetition which is identical to that found in the literay text' (Marais 1988:480). Die metanarratief van die Weste dat sosio-politieke en historiese ontwikkeling die belangrikste is, word dus gedekonstrueer deur die postmoderne narratief se strategieë wat in alles slegs 'n onophoudelike intertekstuele herhaling sien. Die postmoderne teks betrek so die leser om vanuit sy sosio-politieke werklikheid intertekstueel deel te word van die betekenisgewende gebeure. Hy/sy word teen wil en dank ingetrek in 'n proses van hermetaforisering vir die eie tyd.

Die absorbering van die leser by 'n leesgebeure waarin die teks postmodernisties hom/haar in 'n proses van refleksie en selfrefleksie insleur, is paradoksaal omdat dit die leser in die dilemma dompel van betrokkenheid en tegelyk onbetrokkenheid. Die vraag na watter betrokkenheid en watter self ter sprake is, die van die werk of die eie self van die leser, lewer vier moontlikhede op. Die moontlikheid waarvoor Bal kies, is wat sy noem 'metacriticism' ( $\mathrm{Bal}$ 1992:84). Die '... fourth mode of self-reflective reading, is the one in which discursive, reflective reading involves both the self of the work - the way in which it problematizes itself as representation and the self of the critic, whose position as, say, an art historian or a philosopher is also the subject of reflection' (Bal 1992:85). Sy noem dit 'n 'metacritical position' (Bal 1992:85). Hierdie lesersbenadering maak dit moontlik om die historiese posisie van leser en teks in verhouding tot mekaar te stel. Hierdie verhouding het nie soseer te doen met ' $n$ rekonstruksie van die verlede nie as eerder '....an awareness of difference in similarity' (Bal 1992:86). Daarmee bedoel sy dat daar ' $n$ ooreenkoms tussen die self van die leser en die van die teks kan wees, maar dat hulle tog nog van mekaar kan verskil (betrokkenheid èn onbetrokkenheid). Die interessante voorbeeld wat sy gebruik, is dat die fenomeen van skryf by Ester politieke mag beteken, dat dit ook by ons 'mag' kan beteken, maar dan in 'n geheel ander vorm, soos in 'n briefbom wat 'n vernietigende mag is. Deur 'n metakritiese posisie in te neem, kan die leser ' $\ldots$ when involved in the act of reading - the delayed completion of writing - ... be aware both of her or his implicit allegiances (reading is done in dispersal of subjectivity) and of his or her inevitable contribution to action (it is an act)' (Bal 1992:95). Deur byvoorbeld die Bybelboek Ester te lees '.. as about reading-writing, one is led to reflect upon all the issues intricated with it: gender, power, and the state, genocide and otherness, submission and agency, in short, upon history (Bal 1992:96). 
Hierdie verwysing na mag, magsvorme en historisiteit, voer ons na die volgende saak van die historiese betrokkenheid of politieke relevansie van postmodernisme.

\section{POSTMODERNE BETROKKENHEID BY DIE WERKLIKHEID}

Die aanklag uit veral materialisties-dialektiese hoek dat postmodernisme sosio-polities nbetrokke is, dit '.. a retreat into mere aesceticism, fictional game playing ...' (Marais 1988:473) is, gaan nie op nie. Die intense problematisering van die verhouding tussen teks en sosiale konteks beteken nog hoegenaamd nie dat die saak laat vaar word nie. Inteendeel, die postmoderne strategieë word ingespan in 'n 'contestatory effort' (Phillips 1990:33) om deur die leesproses, soos dit in die sosiale raamwerk voorkom, prosedures van bemagtiging te aktiveer.

As dinamiese teken moet die teks voortdurend gekontekstualiseer word. Die postmoderne aandrang op die verwydering van die grens tussen leser, teks en konteks het die teks onttrek van alle verabsoluterende en totaliserende aansprake. Dit is in 'n proses ingesleur waar dit voortdurend sy eie raamwerk, strukture, temas, metodes, interpretatiewe strategieë en oorspronklike doel, oorskry. In hierdie proses vind daar 'n voortgaande sosiale koppeling van die leser en die teks plaas waardeur die waarheid nie soseer ontdek word nie, maar eerder geproduseer word. Die lees en betekenisgewing van die teks geskied binne 'n 'contestary framework' (Phillips 1990:35) waardeur die teks voortdurend in die huidige moment gehou word.

In die denke van Foucault is die lees van 'n teks onlosmaaklik verbind aan die sosiale produksie van waarheid en die uitoefening van mag. Met hierdie 'mag' word iets anders as die tipiese Westerse juridiese kategorie van onderdrukkende mag bedoel. Dit is eerder die moontlikheid om iets waardevol vir ons te produseer, soos om plesier te verskaf, vorms van kennis or te dra, of diskoers moontlikhede te skep. Dit is ' $n$ produktiewe netwerk wat deur die hele gemeenskap gaan, nie bloot net 'n negatiewe onderdrukkende mag nie. Tussen die institusionele strukture wat 'n rol speel in die verspreiding en toekenning van hierdie mag en dit wat bepaal wat waarheid is en gevolglik as waarheid gedefinieer word, bestaan 'n baie noue band. Die historiese ontmoeting tussen die teks en die leser binne die sosiale raamwerk het altyd pragmatiese politieke en ekonomiese konsekwensies. Dit skakel met die institusionele strukture wat die mag het om die waarheid te bepaal en te produseer. Die kritiese diskoers is altyd die plek waar spesifieke vorms van sosiale mag uitgeoefen word. Die eksegetiese tegnieke wat gebruik word en die sosiale kragte wat daardie tegnieke bemoontlik vorm deel van hierdie worsteling om bemagtiging.

Vir 'n postmoderne lees van tekste impliseer dit radikale selfrefleksie en nadenke oor die voorwaardes waarop 'n teks gelees moet word om geldigheid in die kontemporêre gemeenskap te besit. Die konkrete historisiteit waarin gelees word, sal 
ernstig opgeneem moet word. 'n Gevolg van lees vanuit 'n postmoderne ingesteldheid sal wees '... that we will be brought to examine the somatic and social consequences of our reading practices especially as they respond in covert ways to the Unsaid of the metanarratives of the age of man' (Phillips 1990:33-4). 'Die inherente ondermynende ingesteldheid van die postmodernisme en die vrae wat oor betekenisproduksie geopper word, het sosiaalkritiese implikasies wat in bepaalde omstandighede ...'n belangrike bydrae kan lewer' (Van Heerden 1997:250). Vrae wat gevra moet word, is: Wie lees en eksegetiseer tekste? Wie se lesings het mag en gesag? Wat is die institusionele strukture wat op hierdie lesing aandring? Is hulle manlik of vroulik, swart of wit? Die konkrete politieke implikasies en strategieë waarop die resultate toegepas word, sal deeglik bekyk moet word. Onder die druk van postmoderne denke '... we have now to embrace the sociality of our reading and the always already theoretical and ideological role we and our writings play in the social order, in the contests of history' (Phillips 1990:36).

Uit hierdie gedagtes kom onder andere 'n saak soos die 'selfbewuste teks' (Van Heerden 1997:58), waarin dit gaan oor taal se vermoë om in stryd met dominerende magte te tree. Dit loop hand aan hand met die 'institusionele transformasie' (vgl Moore 1994:127) wat wêreldwyd aan die gang is. Leserspraktyke uit die oord van strukturalisme, poststrukturalisme en postmodernisme het ' $n$ skuif meegebring waarin daar 'n oplewing gekom het van die institusionele wat aan die rand lê, terwyl ' $n$ transformasie voltrek word van die institusionele in die tradisionele sentrum. Die opkoms van die feminisme uit die eerste wêreld en die derde wêreld betoeë uit Latyns-Amerika, Afrika en Asië het die ontoereikendheid van die tradisionele begrippe soos geskiedenis, teks, subjek, kritiese lees en betekenis aan die lig gebring. Baie het uit die Aufklärungsdroom van onpartydige navrae en objektiewe waarheid begin wakker word en die haalbaarheid van hierdie benaderings in terme van persoonlike, institusionele en kulturele terme begin bevraagteken.

Die gebruik deur sommige politieke kritici van nie-tradisionele interpretatiewe metodes en die weerstand teen objektiwiteit om ' $n$ teks by die situasie van onderdrukte mense uit te bring, het aan hulle die naam van postmoderne politieke intrepreteerders besorg. Hulle ideologies-kritiese lees van die Bybel is volgens Adam egter nog steeds vasgevang in 'n modernistiese filosofiese posisie waar hulle ' $n$ naïewe en totaliserende posisie van bevoorregte kennis en waarheid inneem en die tekste wat hulle bestudeer ideologies kritiseer. Hulle modernisties georiënteerde beredenering is 'n oop skyf vir postmoderne kritiek: 'Political critics who rely on metanarratives of emancipation, or who assume the people have some innate human rights, are subject to the antifoundational and detotalizing critiques of other postmodern critical discourses' (Adam 
1995:53). 'n Postmoderne siening sou eerder erken dat álle komposisies en álle interpretasies ideologie bevat. Die mense wat tekste opgeskryf het, die sosiale groep wat dit oorgedra het, die wat dit later lees en oordink, redeneer almal ideologies, sodat die lokus van ideologie nie verabsoluteer of tot een plek beperk is nie. 'Postmodern ideological critics will continue to point out the ways that dominant social groups' approaches to the Bible produce and reproduce oppressive social relations, but they will also produce counterreadings to contest the prevalent interpretive customs' (Adam 1995:54). Postmoderne politieke kritiek vorm 'n teenvoeter teen verstokte interpretasie deur uit te wys hoe die lees van die teks steeds van die leser/s se materiële omstandighede afhang. Elke politieke lees van die teks moet deur die postmoderne tendens van demistifikasie gelei word. 'Where critics subject modern (scientific, specialized, systematized) ideologies to demystification and deconstruction, there we discern a different, postmodern political criticism' (Adam 1995:57).

\section{DIE KLEINGESKIEDENIS EN DIE DANIËLAPOKALIPS}

Die genereer van 'n histories verankerde (her-)metafoor waartoe die lees van die Daniëlapokalips ons voer, die postmodernistiese betekenisgewing van die teks om dit in die huidige moment te hou binne die 'contestary framework' (Phillips 1990:35) van 'n Suid-Afrika in 'n polities en kulturele transformatiewe fase, hou verband met die formulering van 'n eie kleingeskiedenis. Vanuit 'n metakritiese posisie van '... an awareness of difference in similarity' (Bal 1992:86) bied die versameling van petite histoires in die Daniëalapokalips die moontlikheid om vanuit 'n eie posisie van onmag tog die reis deur die labarint te onderneem en met die taal van die metafoor '... 'n bres na die werklikheid te probeer slaan' (Van Heerden 1997:57), al blyk dit dat die woord geen glimmende swaard is nie maar slegs '... 'n verraderlike spieël' (Van Heerden 1997:58).

Vanuit my situasie van 'n marginale groep wat 'n klein faksie uitmaak van die Christendom in Suid-Afrika, wat konserwatief Reformatories, Afrikaanssprekend en bykans uitsluitlik blank is, kan die apokalipse van Daniël gelees word om in die kleingeskiedenis van hierdie groep die teks van hulle eie ideologiese raamwerk te parodiseer en tegelyk hulle te bemagtig om as kerk van Jesus Christus die 'countermemory' (Lyotard; vgl Van Heerden 1997:44-5) uit te leef en die 'counterreading' (vgl Adam.1995:54) te propageer dat alle menslike mag tydelik en begrens is. Die kleingeskiedenis van Daniël kan hulle daartoe lei om hulle mag van kerkwees in 'n plurale samelewing voortdurend opnuut te aktiveer deur nie kultuurverwyderd teenoor die historiese moment te staan nie, maar deur '... 'n bepaalde modifikasie van askese' (Venter 1996:629) demistifiserend teenoor elke mag van kriminaliteit en vernietiging in te staan vir die oorwinnende mag van toekomshoop en vertoue op God. 
Die voltooiing van die kleinverhaal van Daniël in die 'historiografiese metafiksie' (Van Heerden 1997:73) van die eie kleinverhaal deur middel van 'n 'contestory dialogic practice' (Phillips 1990:26), bly egter steeds deel van 'n 'nomadiese diskoers' (Van Heerden 1997:14). Dit bly altyd 'n reis deur die labarint, die hantering van 'n 'shifting network of signs' (Phillips 1990:11), 'n worstelende dialoog met teks en historiese konteks waarin elke gekontekstualiseerde nuwe woorḍ 'n verwronge spieëlbeeld van die werklikheid is wat aandring op 'n nuwe poging vorentoe. Dit is 'n 'analitiesreferensiële diskoers' (Hambidge 1992a:62) wat met sy 'imaginative, phantasmagorical and fantastic portrayal of mimetic and marvelous worlds' (Gräbe 1988:371) sy onvermoë tot finale representasie van die werklikheid te kenne gee.

Dit bly altyd 'n beperkte en tydelike woord wat die verhulde geopenbaardheid van die apokalips reflekteer. Dit is altyd ' $n$ woord wat in die oop einde van die apokaliptiese simboliek inbeweeeg met die kritiese wete dat dit weer ewe maklik deur ' $n$ volgende vulling van die simbool vervang kan word. Die kleinverhale in Daniël met hulle fanatasmagoriese visioene van die vier diere (hoofstuk 7), die skaapram en die bokram (hoofstuk 8), die verskyning van die engel Gabriël (hoofstuk 9) en die indrukwekkende visioen in die derde jaar van Kores (10:1-12:4), representeer almal die werklikheid van die honderd en sestigerjare voor Christus in Jerusalem. Dit gebruik egter apokaliptiese taal en begrippe wat die werklikheid rondom Antiogus Epifanes beskryf sonder om ooit sy naam te noem. Dit beskryf sonder om werklik te sê. Dit is in terme van Bal (1992) se analise van Ester die demonstrasie in Daniël van die onmag van die mag van die geopenbaarde woord. Dit is '... a means of presenting a particular truth about existence' (Rowland 1982:58), die radeloosheid met die eie tyd en die millenniaristiese mitologiese projeksie na die toekoms waaroor daar sekerheid is, maar waaroor daar nie anders as in verhulde simbooltaal gepraat kan word nie. By die verlies van rykdom, status en mag (vgl Venter 1996:620) reflekteer hierdie tipe taal die siening dat die werklikheid teenstrydig is, sonder eenheid, dat daar 'n ' artificiality of reality' (Gräbe 1988:377) is. Dit gee uiting an die oortuiging dat die heiligheidsorde totaal versteur is maar op ' $n$ kosmies bepaalde tyd weer herstel sal word. Omdat die '.. oplossing van menslike probleme ... in 'n tyd en ruimte buite hierdie wêreld gesoek' (Venter 1996: 629) word, versterk dit die bewussyn van die ontoereikenheid van taal en die gevoel dat werklikheid teenstrydig en sonder eenheid is. Dit bly steeds 'allusions to the conceivable which cannot be presented' (Lyotard 1984:81). Alles bly onaf. Dit bly steeds 'surfiction' (Hambidge 1992b:51) wat die grense aanhoudend verskuif na die onbekende wat nog ontmoet moet word.

Die kulturele intertekstualiteit van Daniël 7-12 met die historiese, sosiale en literêre tekste van sy tyd is vanuit die postmodernistiese parodisering gesien 'n kritiek op die intertekste:sosiaal en literêr. Daniël 9:24-27 is nie net 'n illokutiewe wysiging van Jeremia 25:11-12 en 29:10, waarna in Daniël 9:2 verwys word nie, aan die hand 
van 'n eiesoortige priesterlike tipe van eskatologie nie, maar is tegelyk 'n aanduiding van 'n ideologiese spanning met ander apokaliptiese groepe uit die geledere van die Hasidim (vgl Venter 1997:78-79) en met Antiogus en sy meelopers. Binne 'n situasie van konkurrensie om mag en invloed, van realisering van tradisionele waardes, van oorlewing en versugting na 'n tyd van herstel van die heiligheidsorde, is die versameling van die Daniëlapokalips ' $n$ inskryf van die eie kleingeskiedenis langs ander kleingeskiedenisse (soos die van Henog en die Makkabeërs) téén die meesternarratief van absolute mag en helleniseringsdruk. Dit is die harde parodisering van koninklke mag en hubris en die sagte parodisering van gewapende weerstand en 'n oorverhitte Naherwartung. Dit is die kleinvertelling van lydsame verset en onkreukbare vertroue op die God van die geskiedenis wat vandag verder geskryf moet word in 'n samelewing van bedrog en geweld.

\section{Literatuurverwysings}

Adam, A K M 1995. What is postmodern biblical criticism? Guides to Biblical scholarship. Minneapolis: Fortress.

Bal, M 1992. Lots of writing. Semeia 54, 77-101.

Brink, A P 1988. Die postmodernistiese roman: 'n Skakel met die 18de eeu? JLS/TLW 4/4, 378-393.

De Villiers, P G R 1991. The end of hermeneutics? On New Testament studies and postmodernism. Neotestamentica 25/1, 145-156.

Eco, U 1984. De Naam van de Roos. Amsterdam: UItgeverij Bert Bakker.

Gräbe, I 1988. Introduction: Postmodernism and reading literature. JLS/LTW 4/4, 359-377.

Hambidge, J 1992a. Post-modernisme (Deel I). Tydskrif vir Lettterkunde XXVI/3, 6269.

1992b. Post-modernisme (Deel II). Tydskrif vir Lettterkunde XXX/3, 48-57.

1995. Postmodernisme. Pretoria: J P van der Walt.

Horsley, R A \& Hanson, J S 1985. Bandits, prophets, and messiahs: Popular movements in the time of Jesus. Minneapolis: Winston Press.

Jobling, D 1992. 'Forced Labor': Solomon's golden age and the question of literary presentation. Semeia 54, 57-76.

Louw, D 1995. Ons taak in postmodernistiese tyd: Straat toe met die evangelie! Die Kerkbode, 17 November 1995, bl 11.

Lyotard, J-F 1984. The postmodern condition: A report on knowledge. Manchester: Manchester University Press.

Marais, M J 1988. The political potential of postmodernist narrative strategies: The case of D M Thomas's Ararat. JLS/LTW 4/4, 472-482. 
Miscall, P D 1992. Isaiah: The labyrinth of images. Semeia 54, 103-121.

Moore, S D 1994. Poststructuralism and the New Testament: Derrida and Foucault at the foot of the cross. Minneapolis: Fortress.

Phillips, G A 1990. Exegesis as critical praxis: Reclaiming history and text from a postmodern perspective. Semeia 51, 7-49.

Redfield, R 1956. Peasant society and culture: An anthropological approach to civilization. Chicago: University of Chicago Press.

Rowland, C 1982. The open heaven: A study of apocalyptic in Judaism and early Christianity. London :SPCK.

Van Heerden, E 1997. Postmodenisme en prosa: Vertelstrategieë in vyf verhale van Abraham $\mathrm{H}$ de Vries. Kaapstad: Human \& Rousseau.

Venter, P M 1996. Daniël 7-12 in sosiaal-wetenskaplike perspektief. HTS 52/4, 605632.

1997a. Daniel and Enoch: Two reactions. HTS 53/1 \& 2, 68-91.

[1997b]. Montage, von Rad en Belydenis. HTS 53/4. (Beplan om te verskyn in November 1997.)

Viljoen, H 1988. Spiël, kamer van spieëls: Oor postmodernisme en representasie. $J L S / L T W 4 / 4,417-426$.

Voelz, J W 1989. Multiple signs and double texts: Elements of intertextuality, in Draisma, S (ed) 1989, Intertextuality in Biblical writings: Essays in honour of Bas van Iersel, 27-43. Kampen: Kok.

Vorster, W S 1989. Intertextuality and Redaktionsgeschichte, in Draisma, S (ed) 1989, Intertextuality in Biblical writings: Essays in honour of Bas van Iersel, 15-26. Kampen: Kok. 